\title{
Structural mapping of Quseir area, northern Red Sea, Egypt, using high-resolution aeromagnetic data
}

\author{
Ahmed Salem ${ }^{1}$, Essam Aboud ${ }^{2}$, Abuelhoda Elsirafy $^{1}$, and Keisuke Ushijima ${ }^{2}$ \\ ${ }^{1}$ Airborne Geophysics Department, Nuclear Materials Authority of Egypt, P.O. Box 530 Maadi, Cairo, Egypt \\ ${ }^{2}$ Earth Resources Engineering Department, Kyushu University, 6-10-1 Hakozaki-ku, 812-8581 Fukuoka, Japan
}

(Received June 17, 2004; Revised May 13, 2005; Accepted May 13, 2005)

\begin{abstract}
Exploration in the northern Red Sea of Egypt has had little success in locating hydrocarbon accumulation. The main exploration problems in this region are the complex block faulting and Miocene salt structures. The complex basement block structure arises from the different ages of faults and the difficulty of determining the exact age relations. In this paper, we present a case study of structural mapping using application of the Euler method to high-resolution aeromagnetic data collected in the Quseir area of the northern Red Sea of Egypt. The results indicated that the area is affected by sets of fault systems, which are mainly trending in the NNW-SSE, NW-SE and NE-SW directions. The results also delineated boundaries of a long and wide magnetic body on the offshore part of the study area. This basement intrusion is most probably related to the Red Sea rift and perhaps associated with structures higher up in the sedimentary section. As a result, the area above this anomaly is highly recommended for further oil exploration. This example illustrates that high-resolution aeromagnetic surveys can help greatly in delineating subsurface structure in the northern Red Sea of Egypt.
\end{abstract}

Key words: Euler method, aeromagnetic, oil exploration, Quseir, Red Sea, Egypt.

\section{Introduction}

Exploration of the Egyptian Red Sea coast began before 1908 when the Gemsa oilfield was discovered on the Red Sea coast near the Gulf of Suez. Consequently, surface mapping and a gravity survey led to the discovery of the Hurghada oilfield. Exploration in the offshore part of the Red Sea shelf started in 1974. Geophysical seismic work followed by drilling of nine deep wells has resulted in noncommercial hydrocarbon shows. Hurghada field is the only oilfield found to date in the Red Sea province. The seismic exploration in the Red Sea entailed numerous problems, such as complex basement faulting and Miocene salt structures. The complex basement block structure arises from the different ages of faults and the difficulty of determining their exact age relations. It was concluded that potential field techniques such as the magnetic method are highly recommended to map the possible subsurface structures.

The magnetic method is one of the best geophysical techniques to delineate subsurface structures. Generally, aeromagnetic maps reflect the spatial variations in the magnetic field of the earth. These variations are related to distribution of structures, magnetic susceptibilities, and/or remanent magnetization. Sedimentary rocks, in general, have low magnetic properties compared with igneous and metamorphic rocks that tend to have a much greater magnetic content. Thus, most aeromagnetic surveys are useful to map structures of the basement and intruded igneous bodies. Fortunately, recent advances in the airborne magnetic

Copyright (c) The Society of Geomagnetism and Earth, Planetary and Space Sciences (SGEPSS); The Seismological Society of Japan; The Volcanological Society of Japan; The Geodetic Society of Japan; The Japanese Society for Planetary Sciences; TERRAPUB systems have made it possible to cover large areas in a considerable time with a high resolution.

A high-resolution aeromagnetic survey has been conducted over the onshore and offshore parts of Quseir area, northern Egyptian Red Sea (Fig. 1) using the facilities of the Airborne Geophysics Department of the Egyptian Nuclear Materials Authority (Salem et al., 1999). In this paper, we present an example of mapping the subsurface structures using the high-resolution aeromagnetic data collected in the Quseir area of the Egyptian northern Red Sea.

\section{Geologic Setting}

The study area covers onshore and offshore parts of the Quseir area (Fig. 1). Geomorphologically, the onshore part (Fig. 2) can be divided into two parts; the Duwi range and the coastal plain. The Duwi range consists of a long sharp ridge, elongated in the northwest direction that drops precipitously to the southwest and slopes gently to the northeast. The elevation of this ridge ranges between $450 \mathrm{~m}$ and $545 \mathrm{~m}$ above see level (ASL). The coastal plain is generally smooth in outline, with no sharp bends or bays. It slopes gently seaward. The relief of the coastal plain is generally low and varies from 6 to $30 \mathrm{~m}$ ASL.

Geologically, the onshore part of the study area is part of the Central Eastern Desert of Egypt. Division of the Eastern Desert of Egypt into northern, central and southern sections is based on basement type (Stern and Hedge, 1985). The Central Eastern Desert was formed by collapse of a small ocean basin or back arc basin (Shackleten et al., 1980). In general, the sedimentary rocks of the onshore part of the study area are separable into two great divisions: the pre-rifting Cretaceous-Eocene group and the 


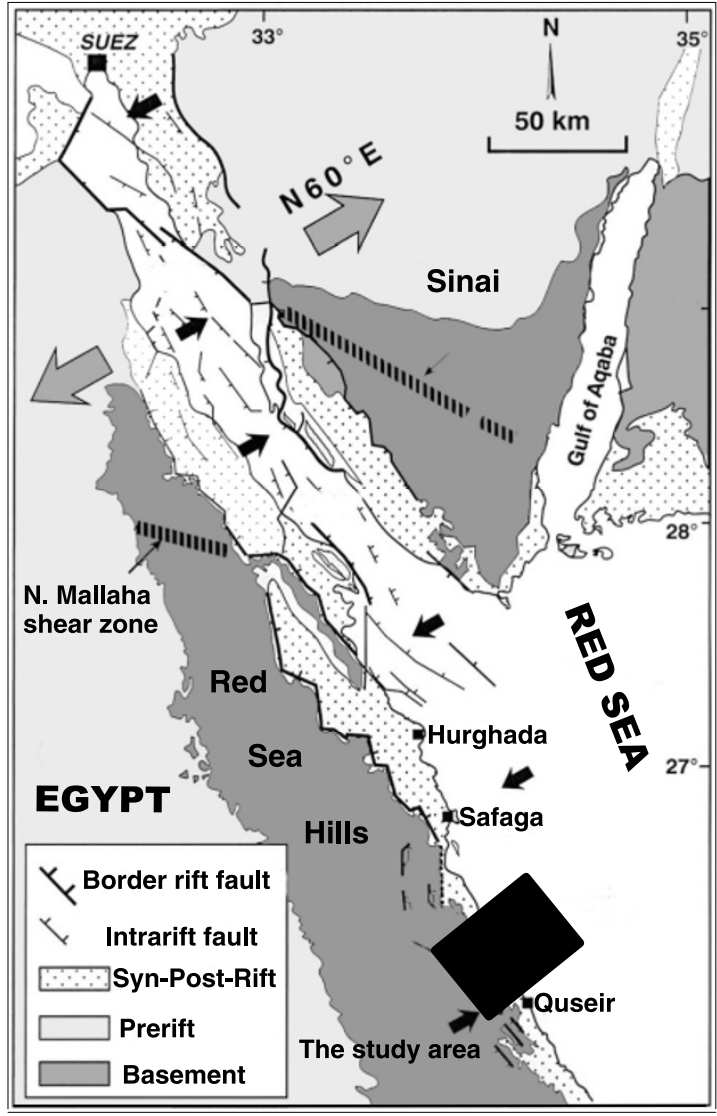

Fig. 1. Location map of Quseir area, northern Red Sea, Egypt.

post-rifting Oligocene and later sediments group. The latter division exhibits a continuous succession from middle Miocene onward. The Cretaceous and Eocene deposits occupy the troughs of synformal-like folds within the crystalline hill ranges. The best example of the pre-rift series outcrops in the Gebel Duwi basin, where more than $1500 \mathrm{~m}$ of Cretaceous and Eocene stratigraphy is exposed from the bottom to the top. The marine upper Eocene and Oligocene deposits are absent, indicating that the region must have undergone elevation changes during these two epochs (Said, 1992).

Several authors have discussed the basement stratigraphy of the Central Eastern Desert of Egypt (Engel et al., 1980; Akkad and Dardir, 1966). In general, the Central Eastern Desert is dominated by rocks of oceanic affinity such as mafic metavolcanic, gabbros, ultramafic and associated metasedimentary rocks (Cochran and Martinez, 1988). The oldest rock units comprise a mafic-ultramafic sequence having ophiolite characteristics. In this region, the basement rocks can be divided into competent granitic intrusions surrounded by less competent zones of metamorphic rocks with intense northwest-striking foliations. The metavolcanic rocks represent pillow tholeiite basalts, which developed on gabbroic and ultramafic substrata of this oceanic sequence. Conformably overlying these oceanic substrata are thick sequences of subduction related immature volcanogenic metasediments, which are conformably overlain by, and interfinger with, island arc type of calc-alkaline volcanic rocks. A major regional unconformity separates the ophilotic, metasediments, metavolcanic, granitic and Dokhan volcanic rocks from a generally unmetamorphosed, dominantly terrigenous sequence of molasse type sediments known as the Hammamat group (El Ramly, 1972). These Hammamat sediments were deposited in intracratonic basins and were preserved in down-faulted blocks, or in topographic lows.

Structurally, the onshore part of the study area is characterized by Precambrian structural features of the AraboNubian shield, which is a system of linear, deep seated leftlateral northwest oriented faults and shear zones (Younes and McClay, 2002). The most prominent of these is the Najd shear zone (Abuzeid, 1988). The northwestern part of the Najd shear zone occurs on the Egyptian side of the Red Sea and is called the Hamrawien shear zone (Fig. 2). In addition to the regional northwest-trending shear zones and faults, pervasive northwest-north-south and east-northeastoriented faults and dikes occur through the basement of the study area.

\section{Aeromagnetic Data}

Figure 3 shows a map of aeromagnetic anomalies of the Quseir area. The regional geomagnetic field (IGRF) and the effects of diurnal magnetic variations were removed (Salem et al., 1999). The aircraft employed in this survey was a Beachcraft C-90-B. A Scintrex split-beam optically pumped cesium magnetometer sensor was used in conjunction with a Scintrex PDAS-1000 data acquisition system. The total field intensity range for this instrument is approximately 20,000 to $100,000 \mathrm{nT}$. A differential GPS system was employed to provide positioning and navigation control. The surveyed area was designed to cover a portion of the Red Sea; the area size is approximately $2500 \mathrm{~km}^{2}$. The area has been surveyed along a set of parallel lines directed $\mathrm{N} 60^{\circ} \mathrm{E}$ at one kilometre spacing. The tie lines were flown $\mathrm{N} 30^{\circ} \mathrm{W}$ at $5 \mathrm{~km}$ spacing. The terrain clearance adopted for the aircraft during normal survey flying was $150 \mathrm{~m}$. Magnetic data were recorded every 0.1 second resulting in geophysical measurements approximately every 10 to 15 meters along the survey lines.

The aeromagnetic map (Fig. 3) shows two regions, the onshore and offshore areas. The former area has a greater density of the contour lines, reflecting changes in the intensity of aeromagnetic data. High-amplitude, shortwavelength magnetic anomalies are seen on the onshore part of the study area. Most of these anomalies are striking in the NNW-SSE and NW-SE, suggesting that the causative structures are related to the main structure trend of the Red Sea. On the offshore region of Fig. 3, the wavelength of the anomalies becomes progressively longer and the density of contour lines is significantly less. An elongated and wide magnetic anomaly could be observed. This anomaly is also trending in the NW-SE direction. There is no geologic information available for the offshore part of the study area so the present study will provide important information about the source of this anomaly.

\section{Interpretation}

The recorded aeromagnetic measurements are very numerous. Traditional methods of interpreting these data, 

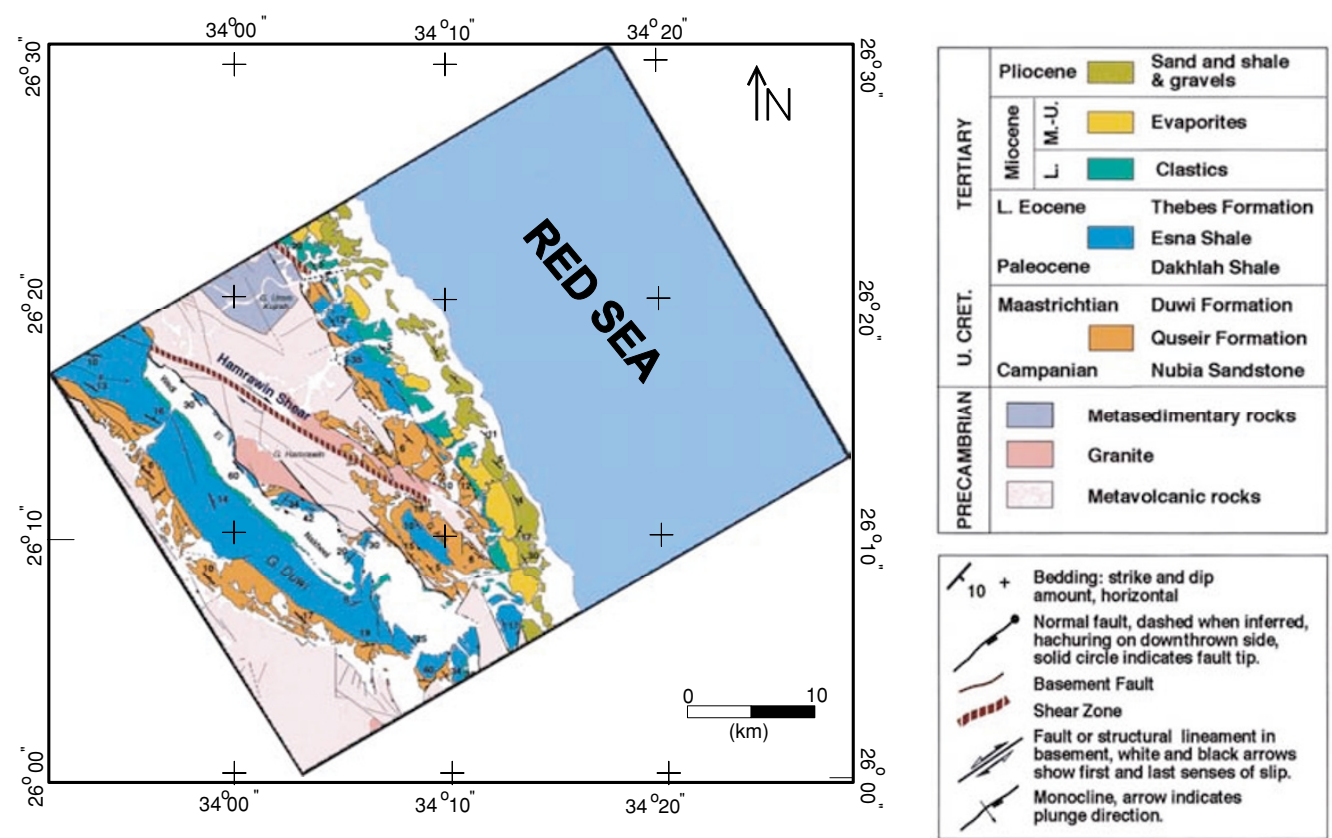

Fig. 2. Geologic map of the Quseir area, northern Red Sea, Egypt.

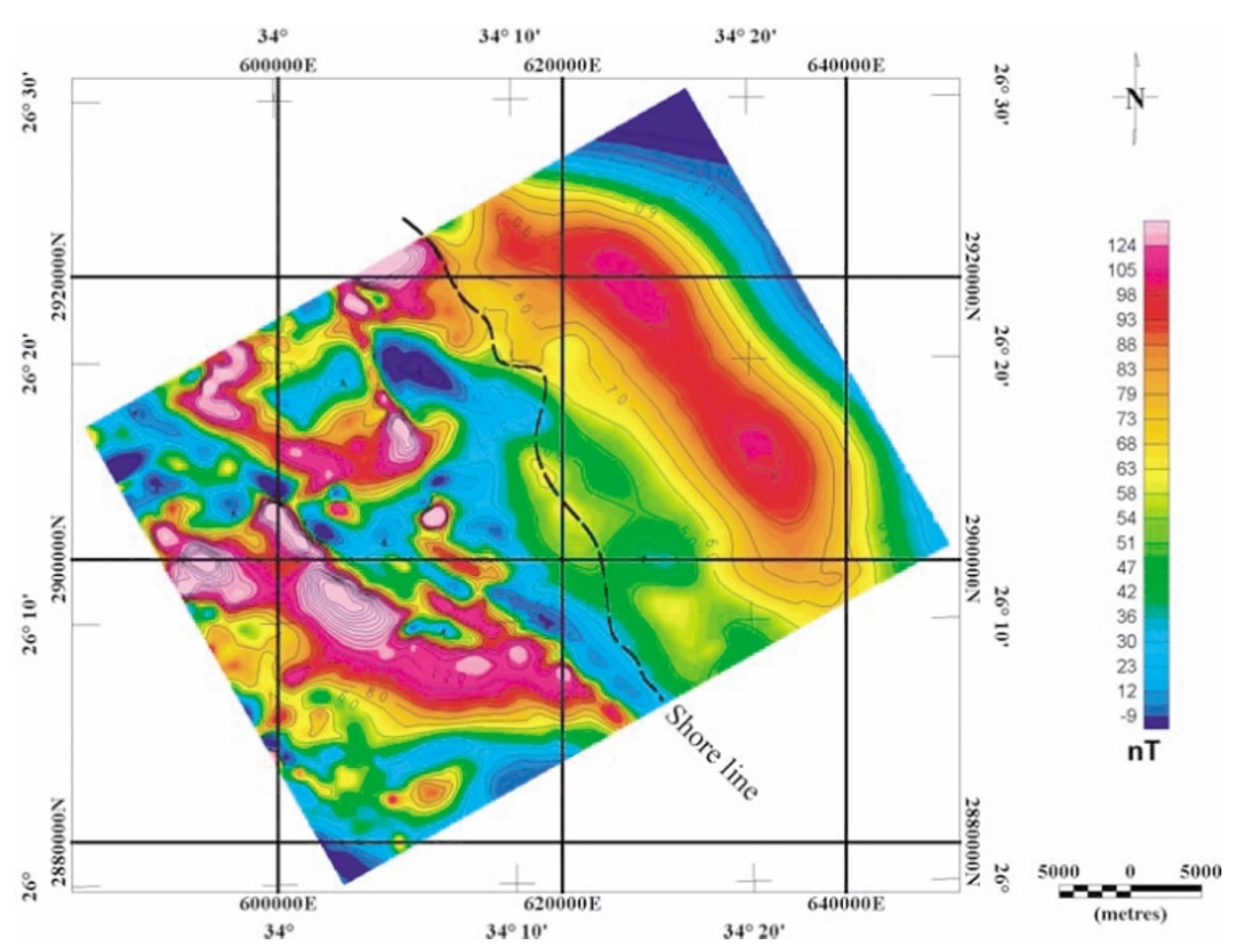

Fig. 3. Total intensity aeromagnetic map of Quseir area, northern Red Sea, Egypt.

such as interpreting line profiles by hand, cannot effectively process such large datasets. In this study we have used the Euler method (Thompson, 1982; Reid et al., 1990) because it is a semi-automatic technique, it requires no prior information about the source magnetization direction, and its results are not affected by the presence of remanence (Ravat, 1996). The 3D Euler equation (Reid et al., 1990) can be written as

$$
x \frac{\partial T}{\partial x}+y \frac{\partial T}{\partial y}+z \frac{\partial T}{\partial z}+\eta T=x_{o} \frac{\partial T}{\partial x}+y_{o} \frac{\partial T}{\partial y}+z_{o} \frac{\partial T}{\partial z}+\eta b
$$

(Thompson, 1982; Blakely, 1995; Ravat, 1996), where $x$, $y$ and $z$ are the coordinates of a point of observation, $x_{o}, y_{o}$, and $z_{o}$ are the coordinates of the source location, and $b$ is a base level. The structural index $\eta$, defines the anomaly attenuation rate at the observation point and depends on the nature of the source; for example, $\eta=0$ for a simple contact, $\eta=1$ for the top of a vertical dike or the edge of a sill, $\eta=2$ for the center of a horizontal or vertical cylinder, and $\eta=3$ for the center of a magnetic sphere or a dipole (Thompson, 1982; Reid et al., 1990). By assuming a value 


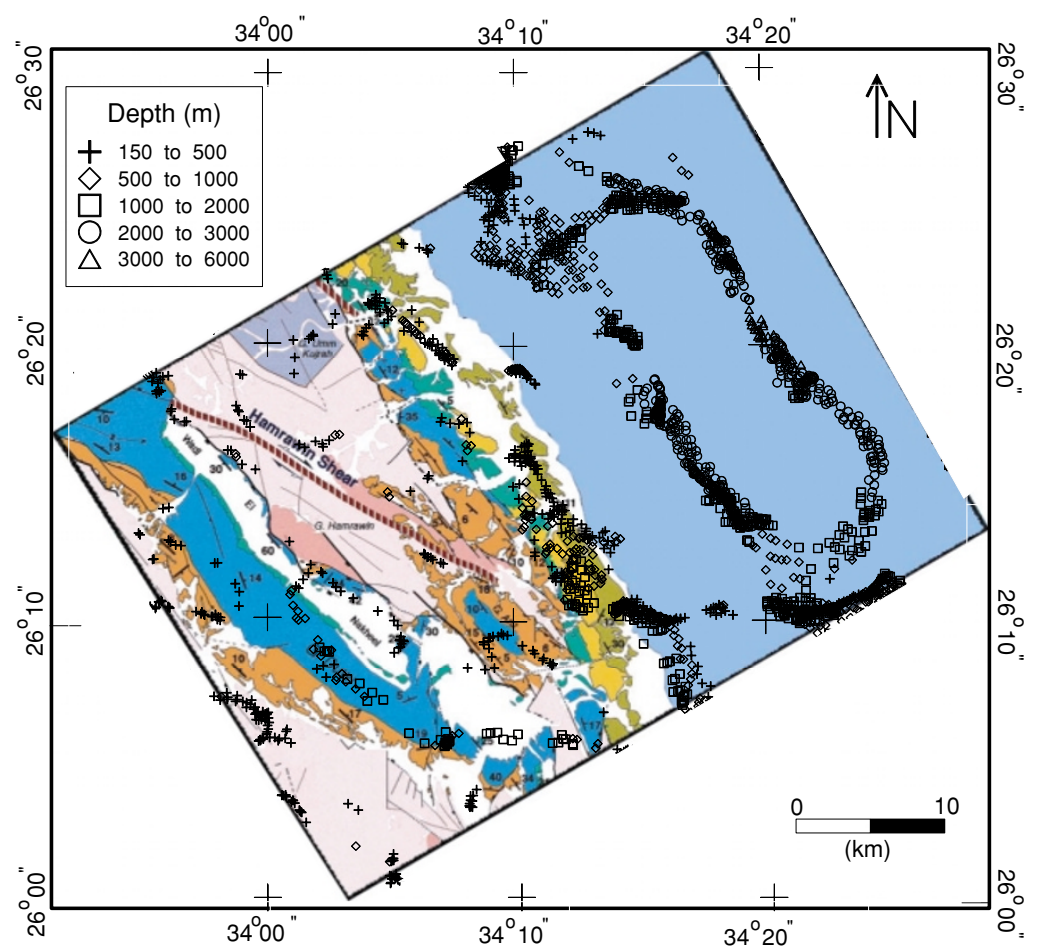

Fig. 4. Solutions of the Euler method using a structural index of contact model.

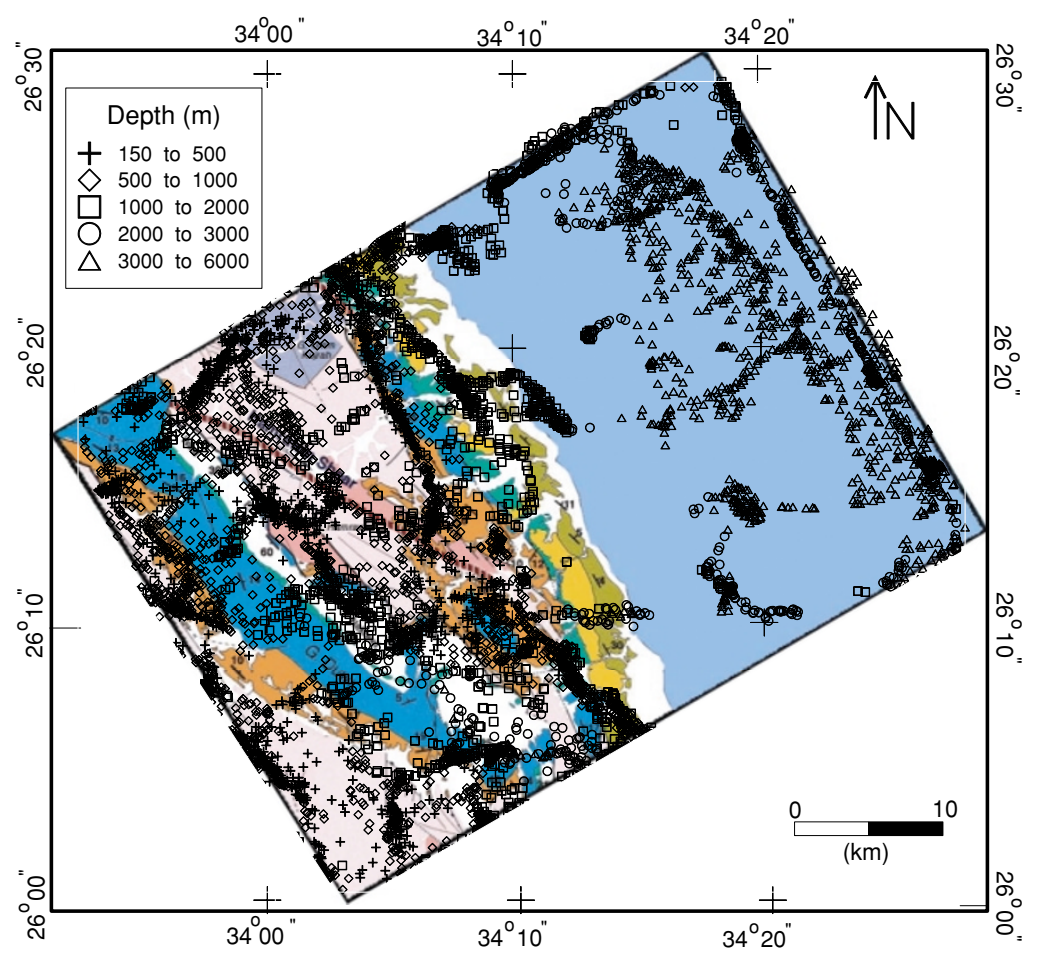

Fig. 5. Solutions of the Euler method using a structural index of dike model.

for $\eta$ and considering four or more neighboring observation points at a time (a movable window), source location $\left(x_{o}\right.$, $\left.y_{o}, z_{o}\right)$ and $b$ can be computed by solving a linear system of equations generated from Eq. (1). Then by moving the window over the anomaly, multiple solutions for the same source are obtained (Ravat, 1996). Finally, a location where these solutions tend to cluster is considered to be the most likely location of the source.

It is well known that the Euler deconvolution method assists in determining the depth and location of magnetic sources from observed magnetic data, but the method has several disadvantages. First, only a few simple geometries satisfy Euler's homogeneity equation (Blakely, 1995). Second, the technique is best suited for sources for which 
the anomaly attenuation rate is constant, such as idealized magnetic sources. For arbitrary sources, the structural index changes with the source-to-observation distance, and this may lead to errors in the depth estimate (Ravat, 1996). Third, the structural index must be assumed as a priori information. Thompson (1982) and Reid et al. (1990), however, showed that the optimum structural index usually yields the tightest clustering of the solutions. Despite these disadvantages, the Euler technique gives satisfactory results in approximating the location of complex bodies.

To apply the Euler method, the aeromagnetic data were first digitized at an equal interval of $250 \mathrm{~m}$ and gradients of the field were calculated in the frequency domain using the FFT method (Blakely, 1995). In this study, the Euler method has been applied assuming two models (contact and dike) with a moving window of $10 \times 10$ data points to locate the possible subsurface structures from the observed aeromagnetic data. Figures 4 and 5 show the Euler solutions for each case (contact and dike, respectively). Solutions were accepted based on the criterion of Thompson (1982). Most of the dike solutions are trending in the NNW and NW directions, associated approximately with the main trend of the Red Sea. In a few locations with the dike model (Fig. 5), solutions are found to be trending in the NE-SW direction. This trend is related to the transformed faults, which is associated with the Red Sea rifting (Said, 1992).

In the onshore part, dike solutions seem to be more clustered than those obtained using the contact model. As mentioned by Thompson (1982) and Reid et al. (1990), selection of an appropriated index (model) will result in good clustered solutions. Thus, the dike model seems to be appropriated for the magnetic anomalies on the onshore part. Generally, the magnetic field over the northern Red Sea takes the form of low amplitude, long wavelength variations on which a number of high amplitude, short wavelength anomalies caused by recent intrusion are superimposed (Cochran and Martinez, 1988). The strong amplitude of these anomalies suggests that the causatives sources are diabasic dikes and probably have a genetic relation to the thermal system of the Red Sea. This expectation was reinforced by the field observations, which indicated that the basement rocks on the onshore part of the study are intensively intruded by diabasic dikes trending in the NNW and NW directions (Abuzeid, 1988).

On the offshore part of the study area, good clustering of Euler solutions are observed when assuming the contact model. Generally the solutions delineate boundaries of an intrusive wide $(10 \mathrm{~km})$ magnetic body with a length of 20 $\mathrm{km}$. The depths associated with the Euler solutions for this body are ranged between $2 \mathrm{~km}$ and $3 \mathrm{~km}$. This body is most probably representing an intrusion that is associated with the Red Sea rift. Such a wide intrusion in the basement would be expected to produce structures higher up in the sedimentary section. We are currently investigating 3D modelling techniques to obtain more accurate information about the shape and magnetization of the intruded body.

\section{Conclusion}

In this paper, we presented a case study of structural mapping using the high-resolution aeromagnetic data of Quseir area, northern Red Sea, Egypt. The study provides information about buried subsurface structures with the help of the Euler method. We have found that dike bodies are appropriated models for the magnetic anomalies of the onshore part. Meanwhile, contact models are good selection of the offshore magnetic anomalies. Generally, the study area is affected by sets of faults systems, which are mainly trending in the NNW-SSE, NW-SE and NE-SW directions. Results of the study, was also able to delineate boundaries of a wide magnetic body on the offshore part of the study area. This body is most probably representing an intrusion associated with the Red Sea rift. However, such a wide intrusion in the basement would be expected to produce structures higher in the sedimentary section. A detailed 3D modelling is highly recommended to delineate more information about the shape and magnetization of this causative source body.

Acknowledgments. We are indebted to all the staff of the Airborne Geophysics Department of the Egyptian Nuclear Materials Authority for their help and supporting this work. Sincere thanks to Dr. Y. Okubo and Dr. Richard Smith for the constructive and thoughtful comments on the manuscript. Thanks for all the staff of the Engineering Geophysical laboratory of Kyushu University for their help and support. We thank Dr. Shigo Okuma for organizing the IUGG 2003 magnetic session and encouraging us to submit this paper.

\section{References}

Abuzeid, H. I., The youngest Precambrian volcanic succession of Wadi Hamrawein, Eastern desert, Egypt, PhD. Thesis., Earth Sc. And Res. Inst. South Carolina, Columbia, USA, 1988.

Akkad, S. and A. Dardir, Geology of Red Sea Coast between Ras Shagra and Marsa Alam with Short Note on Exploratory Work at Gebel el Rusas Lead-Zink Deposits, Geological Survey of Egypt, 1966.

Blakely, R. J., Potential Theory in Gravity and Magnetic Applications, Cambridge Univ. Press, 1995.

Cochran, J. R. and F. Martinez, Evidence from the northern Red Sea on the transition from continental to oceanic rifting, Tectonophysics, 153, 25-53, 1988.

El Ramly, M. F., A new geological map for the basement rocks in the Eastern and Southwestern desert of Egypt: Scale 1:1,000,000, Annals of the Geological Survey of Egypt, 1-18, 1972.

Engel, A. E. J., T. H. Dixon, and R. J. Stem, Late Precambrian evolution of Afro-Arabian crust from ocean arc to craton, Geologic Society of America, Bulletin, 91, 699-705, 1980.

Ravat, D., Analysis of the Euler method and its applicability in environmental magnetic investigations, J. Environ. Eng. Geophys., 1, 229-238, 1996.

Reid, A. B., J. M. Allsop, H. Granser, A. J. Millett, and I. W. Somerton, Magnetic interpretation in three dimensions using Euler Deconvolution, Geophysics, 55, 80-90, 1990.

Said, R., The Geology of Egypt, Elsevier Science Ltd., Rotterdam, Netherlands, 1992.

Salem, A., A. Elsirafi, and K. Ushijima, Design and application of highresolution aeromagnetic survey over Gebel Duwi area and its offshore extension, Egypt, Mem. Fac. Eng., Kyushu Univ., 59(3), 1999.

Shackleten, R. M., A. C. Ries, R. H. Grahm, and W. R. Fitches, Late Precambrian ophiolite melange in the eastern desert of Egypt, Nature, 285, 472-474, 1980.

Stern, R. T. and C. E. Hedge, Geochronologic and isotopic constrains on Late Precambrian crustal evaluation in the Eastern Desert of Egypt, Am. J. Sci., 285, 97-127, 1985.

Thompson, D. T., EULDEPTH: A new technique for making computerassisted depth from magnetic data, Geophysics, 47, 31-37, 1982.

Younes, A. and K. McClay, Development of accommodation zones in the Gulf of Suez-Red Sea rift, Egypt, AAPG Bulletin, 86(6), 1003-1026, 2002.

A. Salem (e-mail: ahmedsalem30@yahoo.com), E. Aboud, A. Elsirafy, and K. Ushijima 